\title{
Synthesis and Characterization of 1-Methyl-3-Methoxysilyl Propyl Imidazolium Chloride - Mesoporous Silica Composite as Adsorbent for Dehydration in Industrial Processes
}

\author{
Javier F. Plata Liévano ${ }^{a}$ Luz A. Carreno Díaz ${ }^{b *}$ \\ ${ }^{a}$ Escuela de Ingeniería Metalúrgica y Ciencia de Materiales, Facultad de Fisicoquímicas, \\ Universidad Industrial de Santander, Colombia \\ ${ }^{b}$ Escuela de Quimica, Facultad de Ciencias, Universidad Industrial de Santander, \\ Cra 27 calle 9 Campus Central Bucaramanga, Colombia
}

Received: September 17, 2015; Revised: January 14, 2016; Accepted: March 1, 2016

\begin{abstract}
Ionic liquid - mesoporous silica composite was synthesized as a new adsorbent for dehydration in industrial processes. An ionic liquid (IL) with proved dehydration properties has been covalently anchored to mesoporous silica. The parameters of the synthesis were studied to produce a solid and stable composite. The material was then characterized by SEM, BET, FTIR, NMR, Raman, XRD, XRF, MALDI and LDI confirming the presence of a covalent bond between the ionic liquid and the solid matrix. Evaluations have shown that the material kept the IL dehydration property.
\end{abstract}

Keywords: Ionic liquid, composite, Immobilized, Porous silica

\section{Introduction}

Silica is an inorganic material broadly used as catalytic support or material for chromatographic columns. Its preparation involves polycondensation of sylanol groups (-Si-OH) from orthosilicic acid $\left(\mathrm{Si}(\mathrm{OH})_{4}\right)$. Through the synthesis, the silicon precursor can interact with porogenic agents or surfactants when added to the reaction media. This sort of substances form micelles, which keep trapped in the growing structure of siloxanes. As a result, a hybrid material is obtained, its organic component can be extracted with solvents otherwise can be calcined to give rise to a solid structure based on an irregular arrangement or irregular channels with silica walls. ${ }^{1,2}$

Ionic liquids (IL) are a synthetic group of chemicals with a growing interest due to their unique properties including melting points below $100^{\circ} \mathrm{C}$, negligible vapor pressures, high thermal stabilities, high viscosities, and the great number of anions and cations available ${ }^{3}$ that allow tailoring the ionic liquids based on the applications. Due to all these properties, there is a broad field of potential applications; our interest is as an extracting media. ${ }^{4}$ The ionic liquid chloride 1-methyl3-methyl imidazolium has been reported as a material with dehydrating properties 5,6

Industrial applications of ionic liquids offer environmental advantages but still have room for improvement, mainly due to their high costs and high viscosity that make applications expensive energetically and economically. In an effort to solve these issues, preparation of immobilized functional ionic liquids (IFILs) has emerged as a better option..$^{7,8}$ These kind of solid composites can be easier handled, separated, regenerated and re-used, the anchoring processes have been used in catalytic processes including esterification, nitration, enzymatic reactions among others ${ }^{9-11}$. The grafting method or valent anchoring method avoid IL leaching and involves an anchor group covalently attached to the surface

*e-mail: lcarreno@uis.edu.co that is used as the cation in the formation of the ionic group, in this way a thin fil of IL is formed on the surface of the support. Here we report the synthesis and characterization of a solid composite based on a mesoporous silica material, covalently bonded to the ionic liquid chloride 1- methyl3 -methoxysilyl propyl imidazolium with application in dehydration processes of industrial interest including natural gas or bioethanol among others.

\section{Experimental}

\subsection{Synthesis of chloride 1-methyl-3-methoxysilyl propyl imidazolium}

Stoichiometric amounts of (3-chloropropyl) trimethoxy sylane (Merck S.A) and 1-methyl imidazolium (Merck, S.A.) were mixed and heated at $78^{\circ} \mathrm{C}$ under inert atmosphere and reflux. The produced chloride 1-methyl-3-methoxysilyl propyl imidazolium was rotoevaporated, washed and dried under vacuum. A yellow viscous material was obtained with $78 \%$ yield. ${ }^{12,13}$

\subsection{Synthesis of mesoporous silica}

For this synthesis, according to the nature of the surfactant and $\mathrm{pH}$ of the synthesis media, three main types of interactions are involved. In alkaline media, where the siliceous species bear negative charges $(\mathrm{I}-)$, the interactions with cationic surfactant $\left(\mathrm{S}^{+}\right)$are electrostatic $\left(\mathrm{S}^{+} \mathrm{I}\right) ;{ }^{14}$ non-ionic surfactants $\left(\mathrm{S}^{0}\right)$ used in neutral media, allow hydrogen bonds and Van der Waals interactions $\left(\mathrm{S}^{0} \mathrm{I}^{0}\right) .{ }^{15} \mathrm{In}$ acidic media, the interaction between the silica and the surfactant is mediated by $\mathrm{X}^{-}$anions as described by $\mathrm{S}^{+} \mathrm{XI}^{-}{ }^{+11}$; in this case glycerol was used as porogenic agent (a renewable, non-toxic, highly available and cheap material) ${ }^{16}$ and TEOS (tetraethoxysilane) (Merck S.A) as siliceous source. In the first step, hybrid 
micelles were formed by interaction between the glycerol and TEOS under controlled $\mathrm{pH}$. In the second step, the condensation reaction occurred by addition of $\mathrm{NaF}$, which is both the starter of the poly-condensation reaction and the precursor of the material with meso- structural properties.

After evaluation of different reaction parameters it was determined that using $\mathrm{CH}_{3} \mathrm{COOH}$ at $\mathrm{pH} 2$ as a reaction media, molar ratios TEOS: Glycerol and NaF:TEOS of $1: 6$ y $1: 10$, respectively and dried at $90^{\circ} \mathrm{C}$ for 12 hours, allows to synthesize $\mathrm{SiO}_{2}$ with $85 \%$ yield.

\subsection{Synthesis of 1-methyl-3-methoxysilyl propyl imidazolium chloride - mesoporous silica composite}

A mix of Ionic liquid/silica with a molar ratio of 0,2 was heated at $90^{\circ} \mathrm{C}$ for 24 hours, the produced composite was filtered and then washed with methanol.

\subsection{Characterization}

FTIR and Raman spectra were recorded on a Tensor 27 Bruker with an ATR cell and a Raman confocal microscope LabRam High Resolution (HR) from Horiba, respectively. $\mathrm{X}$-ray diffraction (XRD) patterns were recorded on a BRUKER model D8 ADVANCE equipped with a graphite monochromator powder diffraction system using $\mathrm{Cu} \mathrm{K} \alpha 1$ radiation of $0.15406 \mathrm{~nm}$ wavelength operated at $40 \mathrm{kV}$ y $30 \mathrm{~mA}$. The BET (Brunauer-Emmett-Teller) specific surface areas were calculated using adsorption data in a relative pressure range of $\mathrm{P} / \mathrm{P} 0=0.05-0.25$. Pore size distribution curve was calculated from the adsorption branch using the $\mathrm{BJH}$ (Barrett-Joyner-Halenda) method. The total pore volumes were estimated from the amounts adsorbed at a relative pressure $(\mathrm{P} / \mathrm{P} 0)$ of 0.99 . Quantitative analysis was performed by XRF on a dispersive wavelength instrument 4KW BRUKER model S8 TIGER. Scanning electron microscopy (SEM) was performed using a FE-SEM QUANTA FEG 650 (FEI) system with a LFD detector, at $7 \mathrm{kV}$ equipped with EDX. NMR spectra were recorded on a Bruker Advance III $400 \mathrm{MHz}$ Ultrashield. Mass spectra were recorded using LDI (Laser Desorption Ionization) and MALDI with CHCA as matrix using a Bruker Ultraflextreme MALDI TOF-TOF (Bruker Daltonics, Billerica, MA).

\section{Results and discussion}

The ionic liquid was synthesized as explained before; the characterization included FTIR spectrum, the assignment of the spectrum bands corresponds with functional groups presents in its structure. $\mathrm{KBr}$ liquids cell: $3363(\mathrm{OH}), 3140$ $(\mathrm{C}=\mathrm{C}), 2947\left(\mathrm{CH}_{2}\right), 2841\left(\mathrm{CH}_{3}\right), 1568(\mathrm{C}=\mathrm{C}) 1460\left(\mathrm{CH}_{3}\right)$, $1182\left(\mathrm{Si}-\mathrm{O}-\mathrm{CH}_{3}\right), 1070\left(\mathrm{Si}-\mathrm{O}-\mathrm{CH}_{3}\right), 810(\mathrm{Si}-\mathrm{C})$. These observations indicate that the organic silica structure keeps unchanged during the anchoring process. NMR spectrum allowed correlation of every type of signal to the corresponding protons in the molecular structure as shown in Figure 1.

${ }^{1} \mathrm{H}$ NMR $\left(400 \mathrm{MHz}, \mathrm{D}_{2} 0\right): \delta(8.67,2 \mathrm{H}) \delta(7.56-7.29,2 \mathrm{H})$ $\delta(4.13,4 \mathrm{H}) \delta(3.82,6 \mathrm{H}) \delta(3.54-3.36,2 \mathrm{H}) \delta(3.25,9 \mathrm{H})$ $\delta(1.87,4 \mathrm{H}) \delta(0.73-0.46,4 \mathrm{H})$. Signals integration showed duplicity for the corresponding signals of propyl imidazolium, which is explained by considering the presence of a cluster. Analysis by MALDI using CHCA as matrix was performed to confirm the cluster formation; the approach shown between 300 and $400 \mathrm{~m} / \mathrm{z}$ in Figure 2 presents the m/z 369 corresponding to the cluster mass: the proposed structure for it is shown in Figure 3.

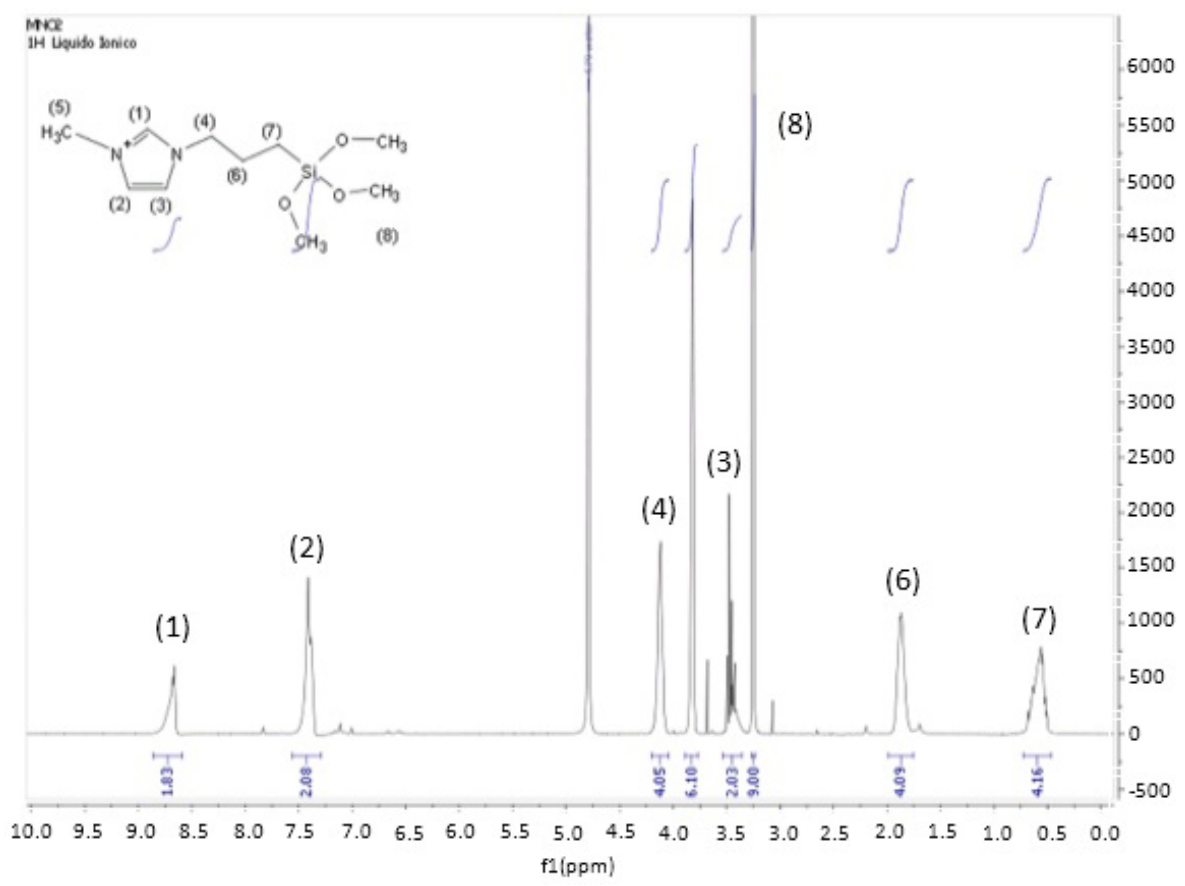

Figure 1. Spectrum NMR of 1-ethyl-3-methoxysilyl propyl imidazolium 


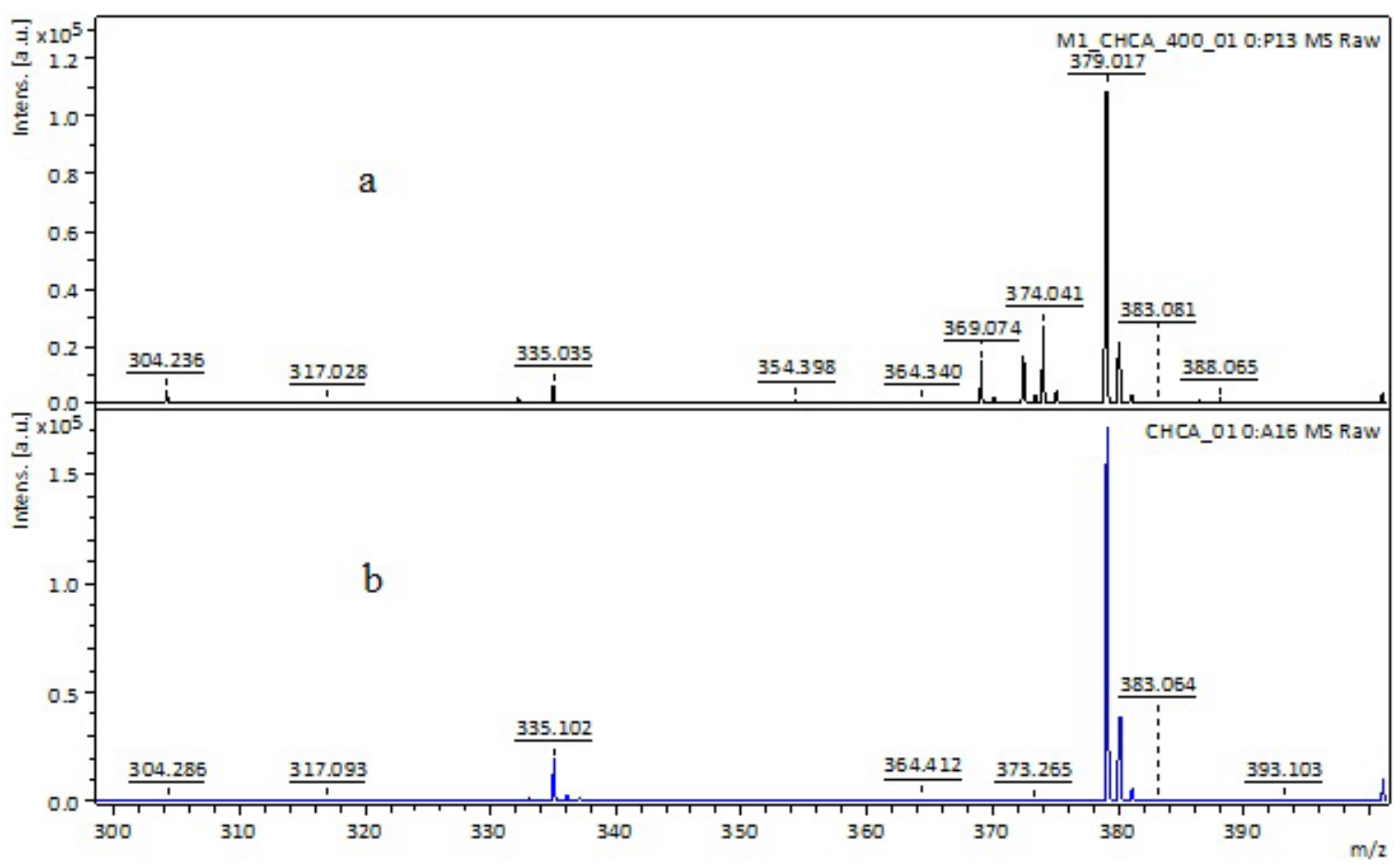

Figure 2. MALDI spectra: a. Spectrum of 1-methyl-3-methoxysilyl propyl imidazolium with the matrix CHCA b. Spectrum MALDI of the matrix CHCA. Approach between 300-400 m/z.

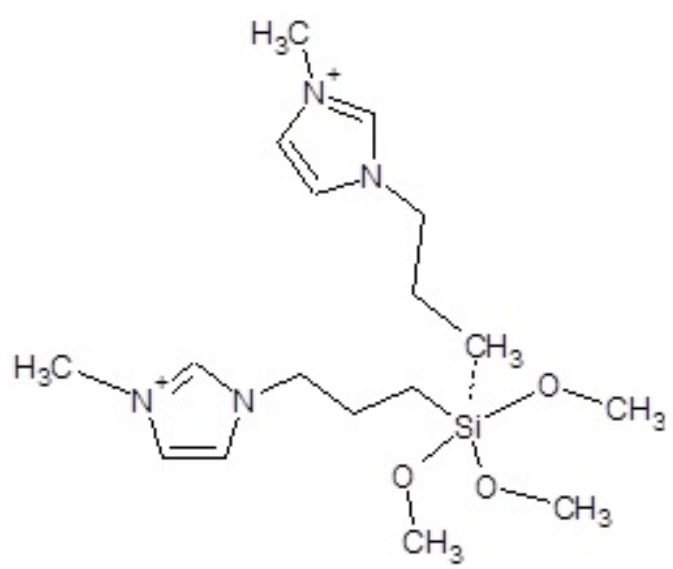

Figure 3. Proposed structure for the ionic liquid cluster

Additional characterization of the ionic liquid included analysis by laser desorption ionization (matrix free used for small molecules). The molecular mass of the ionic liquid is $280 \mathrm{Da}$, however the molecular ion is neutralized by the chloride counter ion, in consequence, the expected molecular ion must be $245 \mathrm{~m} / \mathrm{z}$ as observed in the corresponding spectra shown in Figure 4.

SEM as shown in Figure 5 allowed observation of the synthesized silica morphology; amorphous particles are observed most of them with micrometric size as shown at different optical magnifications, the average sized is between 90-120 $\mu \mathrm{m}$, aggregates are not observed meaning a proper dried process of the gel. BET analysis determined an average surface area of $104.02 \mathrm{~m}^{2} / \mathrm{g}$ and an average pore size of $28 \mathrm{~nm}$. Quantitative analysis by FRX showed a $\mathrm{Si}$ content of $44,7 \%$ a $4,3 \%$ of error when compared with the theoretical value.

Qualitative analysis by XRD showed a profile characterized by a broad band typical of an amorphous material. Comparison with profiles reported at the PDF-2 del International Center for Diffraction Data (ICDD) database determined the presence of quartz $\mathrm{SiO}_{2}$ in addition to a second phase of Malladrite $\left(\mathrm{Na}_{2} \mathrm{SiF}_{6}\right)$, as a result of the reaction of $\mathrm{SiO}_{2}$ with the catalyst $\mathrm{NaF}$. See Figure 6.

Once the ionic liquid and the solid matrix were synthesized, the immobilization was realized through a process named grafting. In this process a covalent bond is created and the ionic liquid in confined in the matrix material ${ }^{17}$. The idea was to prepare a heterogeneous material supporting the ionic liquid on a high surface area and good mechanical stability material. Through the process, the active sites are increased in this case for dehydration purposes using the ionic liquid more efficiently with less quantity.

SEM images in Figure 7 let see the morphology and surface patterns of ionic liquid on $\mathrm{SiO}_{2}$, in addition, it is clear from the image that the $\mathrm{SiO}_{2}$ structure did not suffer any kind of modification after the immobilization process as reported before for other type of matrices. ${ }^{18}$ Images in Figure 9 showed non-homogeneous aggregates of micrometric size uniformly distributed on a particle of $\mathrm{SiO}_{2}$. BET analysis determined a surface area of $71.23 \mathrm{~m}^{2} / \mathrm{g}$ and a pore size of $8.74 \mathrm{~nm}$.

The covalent linkage of the ionic liquid moieties to the silica framework and the ionic liquid moieties content in the composite were assessed by ${ }^{19} \mathrm{Si}$ NMR technology as shown in Figure 8. The spectrum displayed five distinct resonances centred at $-111,-102,-93,-67$ and -57 ppm that can be 


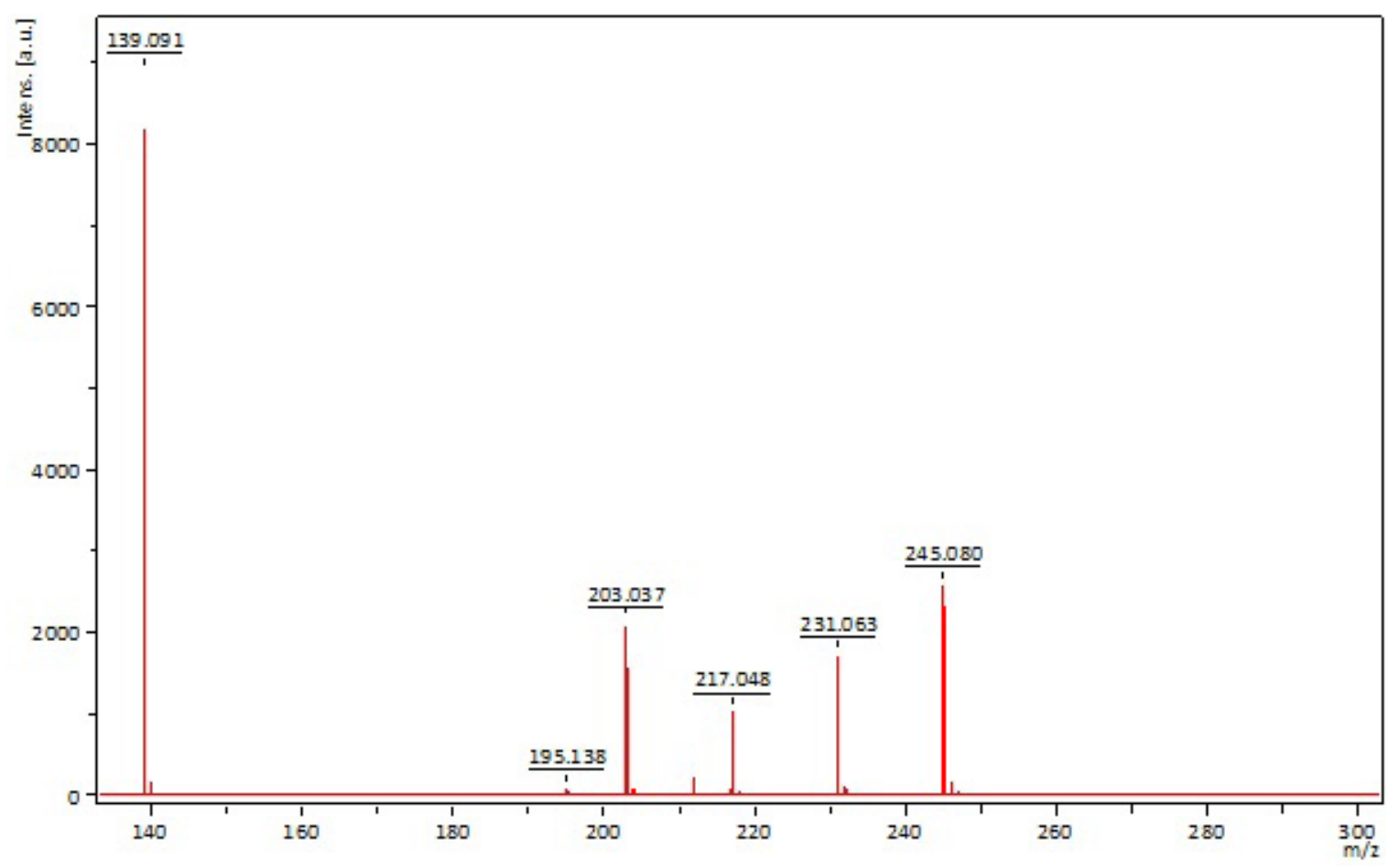

Figure 4. LDI spectrum of 1-methyl-3-methoxysilyl propyl imidazolium

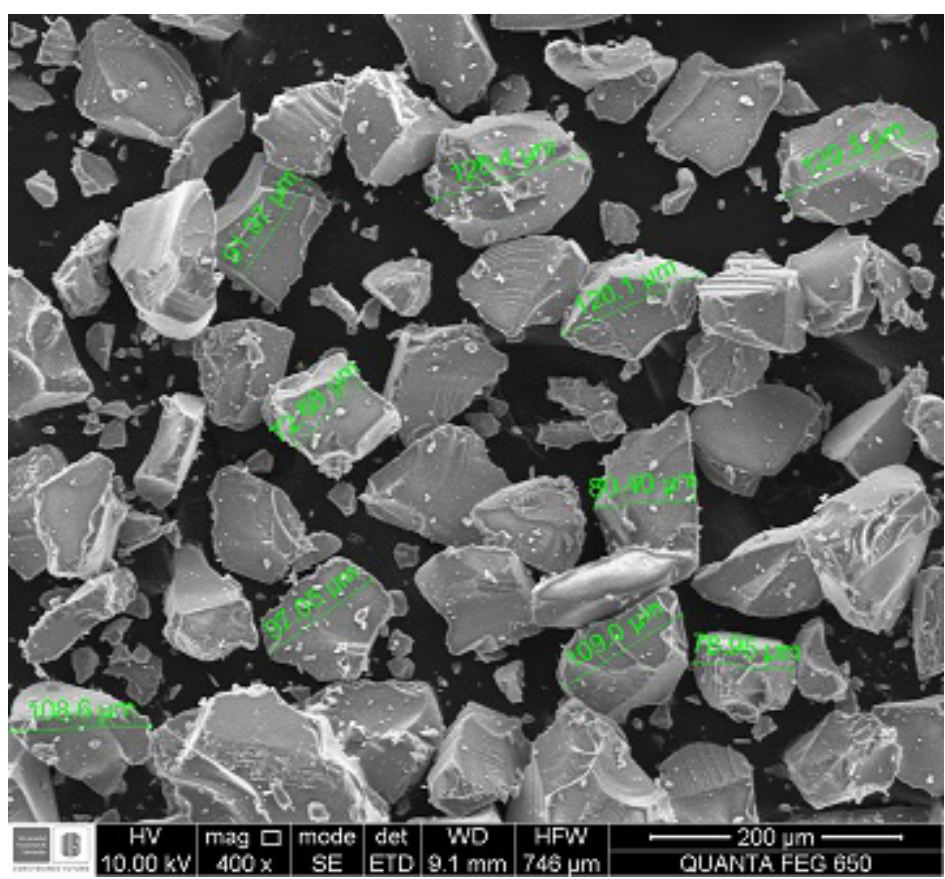

Figure 5. SEM Image of synthesized $\mathrm{SiO}_{2}$ particles at $200 \mu \mathrm{m}$

assigned, respectively to, $\mathrm{Si}(\mathrm{OSi})_{4}\left[\mathrm{Q}^{4}\right],(\mathrm{HO}) \mathrm{Si}(\mathrm{OSi})_{3}\left[\mathrm{Q}^{3}\right]$, $(\mathrm{HO})_{2} \mathrm{Si}(\mathrm{OSi})_{2}\left[\mathrm{Q}^{2}\right], \mathrm{RSi}(\mathrm{OSi})_{3}\left[\mathrm{~T}^{3}\right]$ and $\mathrm{RSi}(\mathrm{OSi})_{2}(\mathrm{OH})\left[\mathrm{T}^{2}\right]$ environments about silicon. The appearance of $\mathrm{T}^{\mathrm{m}}$ signals ( $\mathrm{RSi}(\mathrm{OSi}) \mathrm{m}(\mathrm{OH})_{3}-\mathrm{m}$ being $\mathrm{R}$ the structure of the IL and taking $\mathrm{m}$ values of 3 and 2 to form the structures) evidences the existence of $\mathrm{Si}-\mathrm{C}$ in the framework and thus the effective incorporation of the ionic liquid moieties. The relative integrated intensities of organosiloxane $\left(\mathrm{T}^{\mathrm{m}}\right)$ and siloxane $\left(\mathrm{Q}^{\mathrm{n}}\right)$ signals calculated in the form of $\mathrm{T}^{\mathrm{m}} /\left(\mathrm{T}^{\mathrm{m}}+\mathrm{Q}^{\mathrm{n}}\right)$ allowed the quantitative assessment of the incorporation degree of the ionic liquid moieties. The measured ionic liquid moieties content was $0.21 \mathrm{mmol} / \mathrm{mol}$ of $\mathrm{SiO}_{2}$, which is close to that expected on the basis of the initial mixture $\left(0.80 \mathrm{~mol} / \mathrm{mol}\right.$ of $\left.\mathrm{SiO}_{2}\right){ }^{19-21}$ 


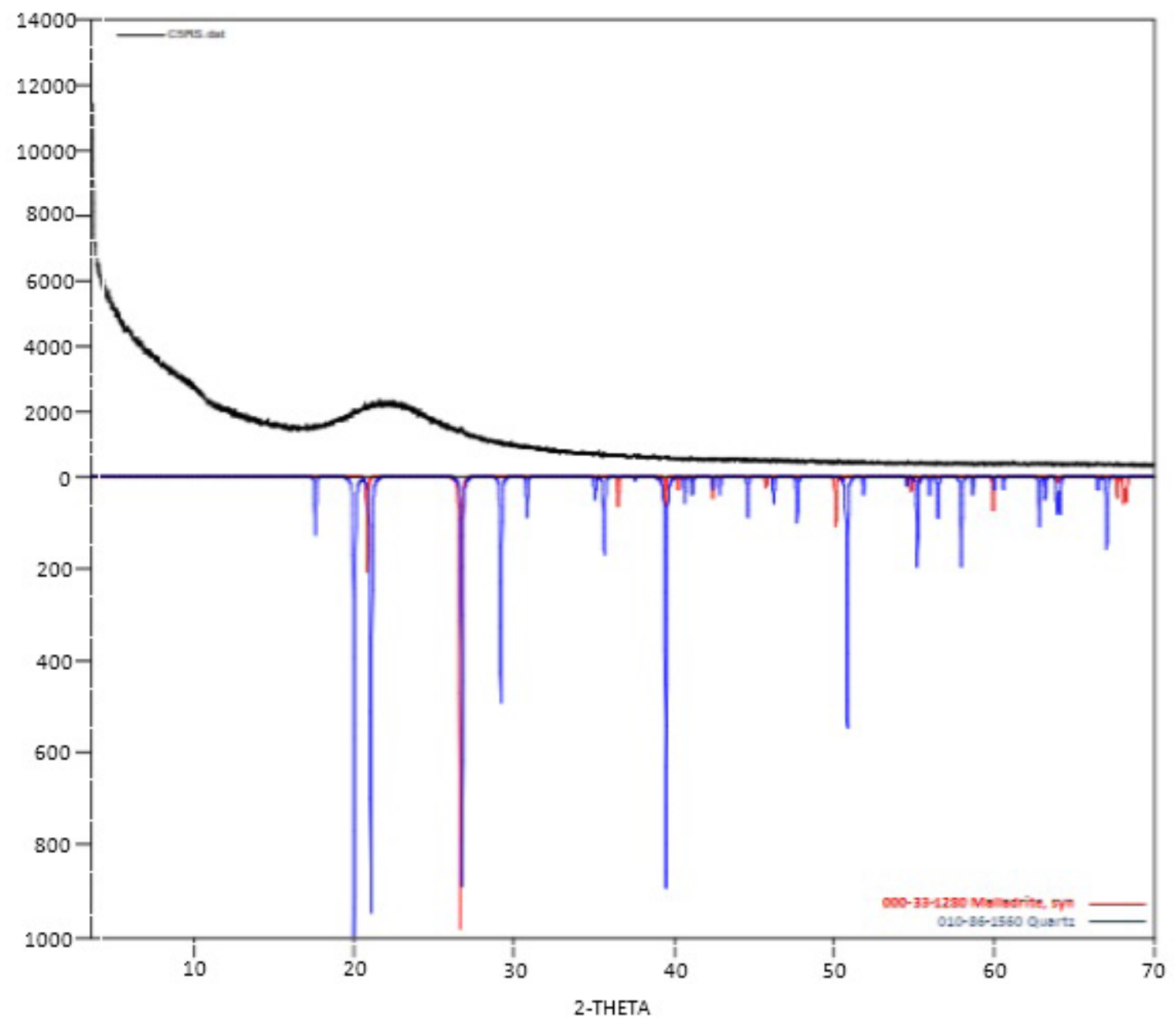

Figure 6. Diffraction profile of synthesized $\mathrm{SiO}_{2}$.

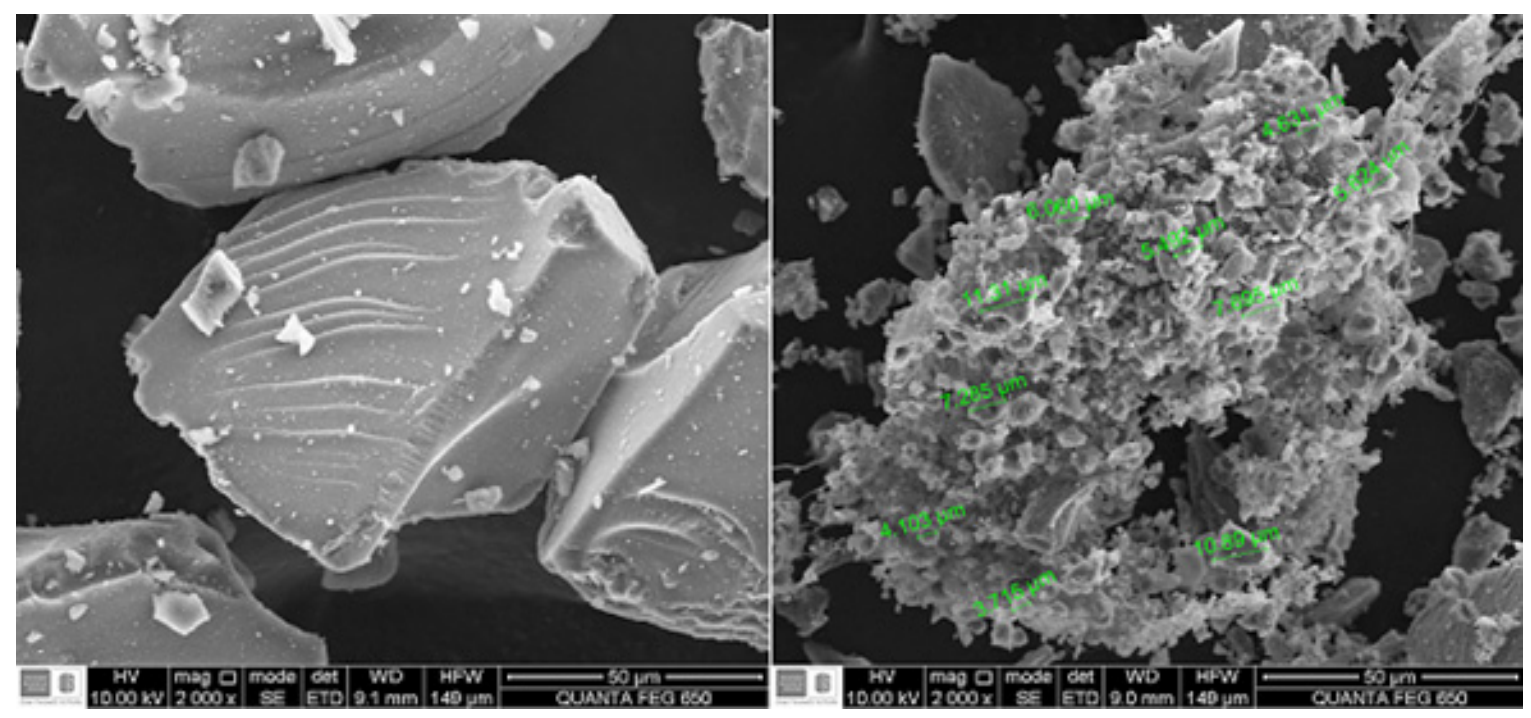

Figure 7. SEM images: on the left pure $\mathrm{SiO}_{2}$, on the right the composite (immobilized IL) 


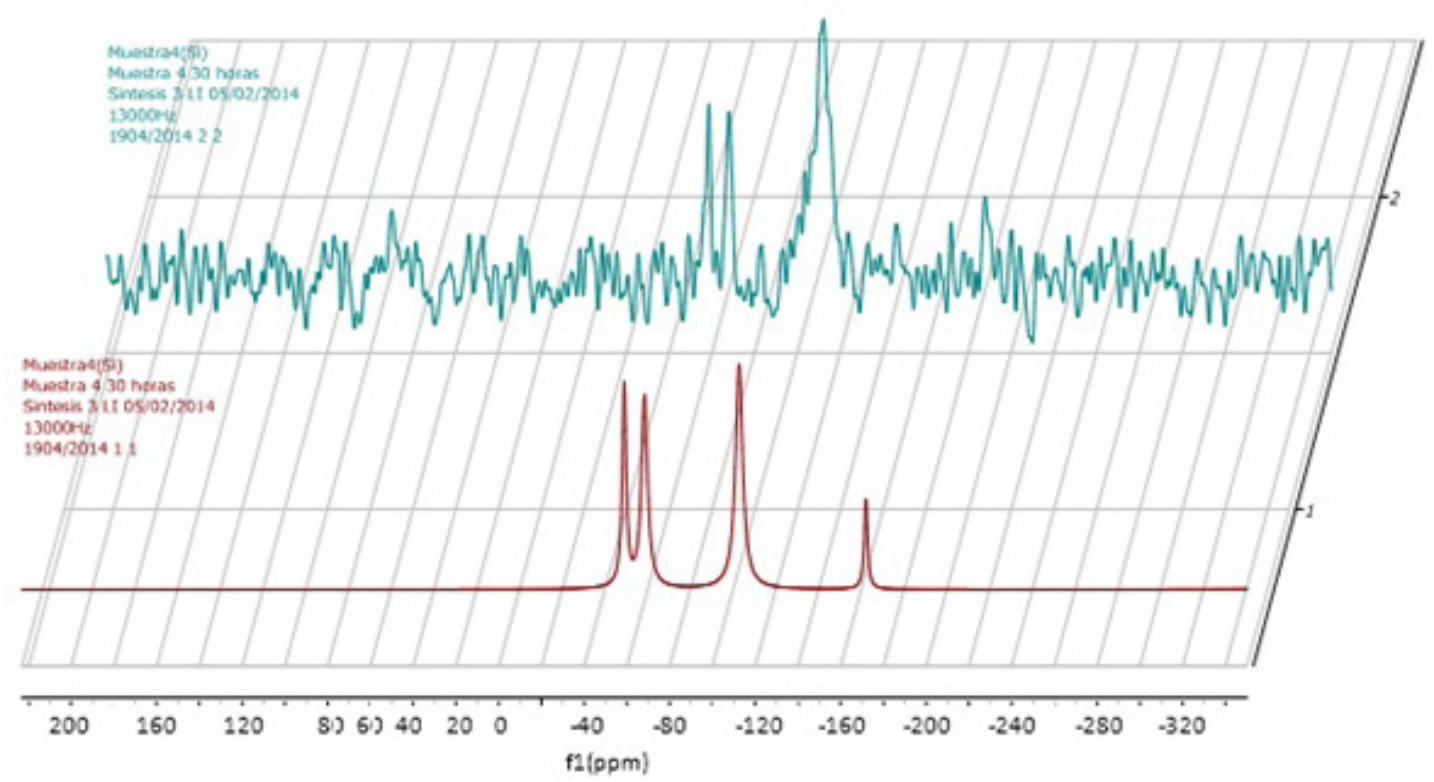

Figure 8. $\mathrm{RMN}$ - 29Si spectrum IL immobilized on $\mathrm{SiO}_{2}$ surface

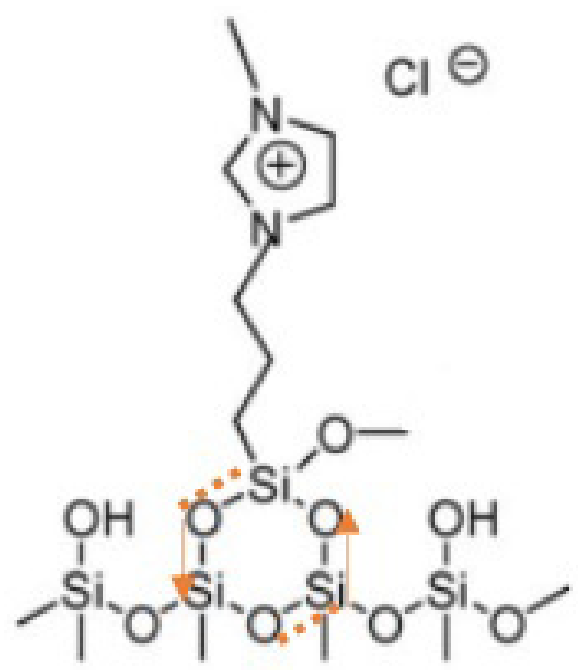

Figure 9. Proposed structure of the ionic liquid immobilized on $\mathrm{SiO}_{2}$

Raman characterization of the composite before and after the immobilization process was performed; spectra are shown in Figure 10. In addition to proper $\mathrm{SiO}_{2}$ signals appear two bands at 597 and $623 \mathrm{~cm}^{-1}$ from quadrant in-plane bend vibrations in imidazolium ring. The spectra is typically dominated, by a very strong band in the 1050 and $980 \mathrm{~cm}^{-1}$ region that involves the 2,4,6 carbon radial stretch from the imidazolium ring, in addition to the weak $\mathrm{Si}-\mathrm{O}$ signals at 790 and $880 \mathrm{~cm}^{-122}$, these observations allowed to confirm the presence of the ionic liquid on $\mathrm{SiO}_{2}$ surface.
Evaluation of the composite has been performed by determining the dehydration percentage of bioethanol $93.45 \% .0,15 \mathrm{~g}$ of the composite was set in a quartz reactor with an internal diameter of $4 \mathrm{~mm}$. The reactor temperatures evaluated were $60,70 \mathrm{y} 80^{\circ} \mathrm{C}$, with feed flows of bioetanol of $0.1,0.2,0.3$ y $0.4 \mathrm{~mL} / \mathrm{min}$ and $-\mathrm{N}_{2}$ - as carrier gas at 130 , 100 y $80 \mathrm{~mL} / \mathrm{min}$. The experimental design showed that nitrogen flow at $80 \mathrm{ml} / \mathrm{min}$, the reactor at $80^{\circ} \mathrm{C}$ and bioethanol flow at $0.1 \mathrm{~mL} / \mathrm{min}$ that amount of composite is capable of removing above $61 \%$ of the water as shown in Figure 11. 


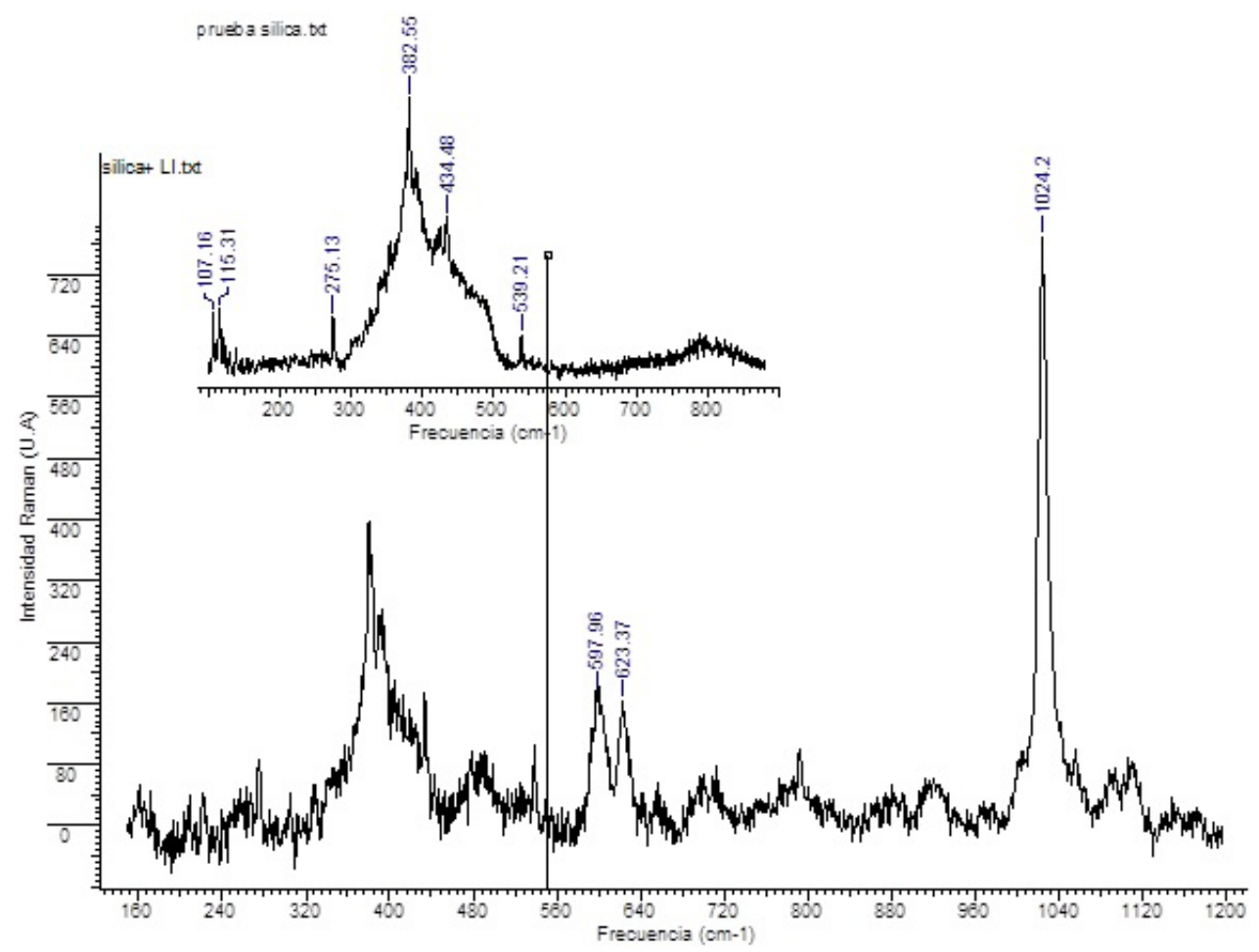

Figure 10. Raman spectra of $\mathrm{SiO}_{2}$ and ionic liquid immobilized on $\mathrm{SiO}_{2}$

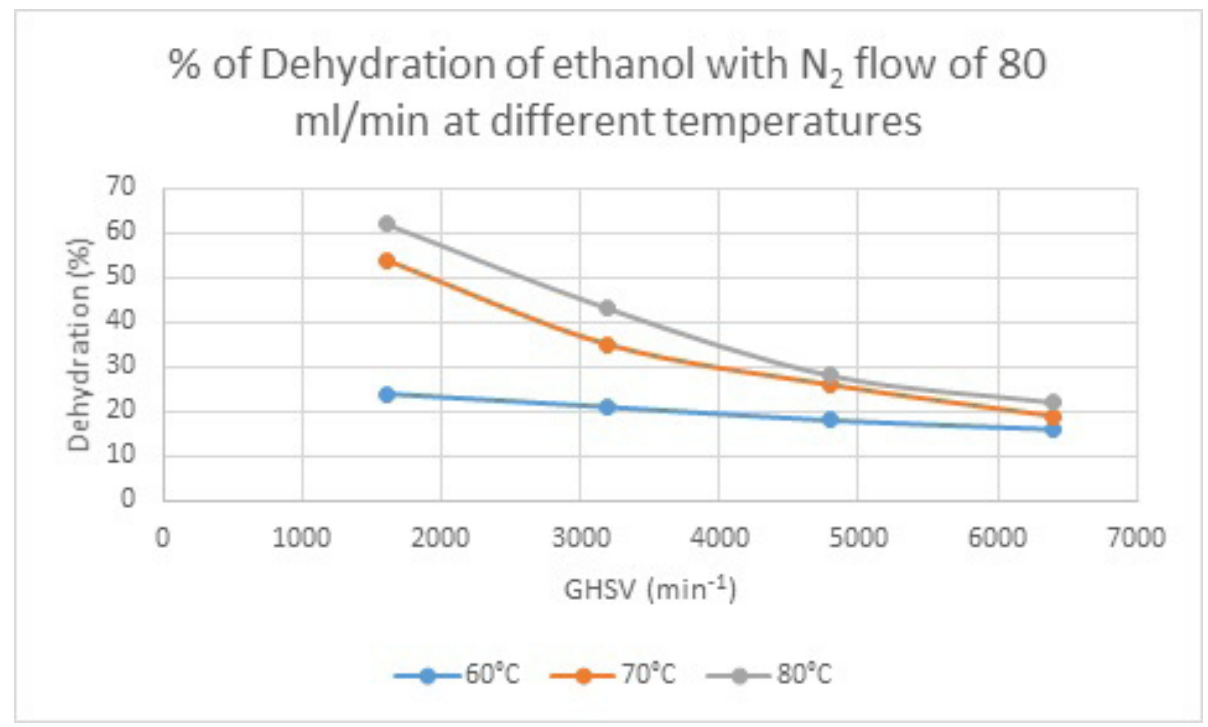

Figure 11. Dehydration of ethanol (93.45\%) using the composite on a fix bed reactor with a nitrogen flow of $80 \mathrm{ml} / \mathrm{min}$ at different temperatures.

\section{Conclusion}

A composite was prepared by bonding the 1-methyl3-methoxysilyl propyl imidazolium to the mesoporous matrix of silica. A covalent bond between the methoxisylil and the hydroxy groups on the silica has been created by the grafting method. The composite material led to a more heterogeneous environment for the dehydration been with the mass ratio used $\left(\mathrm{IL} / \mathrm{SiO}_{2}=0.2\right)$ a solid material, of easy preparation and handling and with application in a fix bed reactor.

\section{Acknowledgments}

Authors thank MS, XRD, XRF, NMR, Raman Spectroscopy and Microscopy Laboratories for all analysis performed, and the great service during data acquisition at Parque Tecnológico de Guatiguará - UIS. Support from the Universidad Industrial de Santander-Colombia Vicerrectoría de Investigaciones. 


\section{Referencies}

1. Liu J, Yang Q, Zhao X, Zhang L. Pore size control of mesoporous silicas from mixtures of sodium silicate and TEOS. Microporus Mesoporous Materials. 2007;106:62-67.

2. Mesa M, Sierra L, Guth, J. Contribution to the study of the formation mechanism of mesoporous silica type SBA-3. Microporus Mesoporous Materials. 2007;102(1-3):70-79. doi:10.1016/j.micromeso.2006.12.009

3. Salvador AR. Líquidos iónicos a temperatura ambiente: un nuevo medio para las reacciones químicas. Revista Royal Academia de Ciências Exactas Físicas Nat. 2008;102(1):79 - 90.

4. Wishart J, Castner E, Shirota H. Intermolecular dynamics, interactions, and solvation in ionic liquids. Accounts of Chemical Research. 2007;40(11):1217-1227.

5. Ge Y, Zhang L, Yuan X, Geng W, Ji J. Selection of ionic liquids as entrainers for separation of (water + ethanol). The Journal of Chemical Thermodynamics. 2008;40(8):1248-1252. doi:10.1016/j.jct.2008.03.016

6. Cáceres O, Plata J. Universidad Industrial de Santander. Tesis de grado. Bucaramanga-Colombia, 2012.

7. Van Doorslaer C, Wahlen J, Mertens P, Binnemans K, De Vos D. Immobilization of molecular catalysts in supported ionic liquid phases. Dalton Transactions. 2010;39(36):8377-8390.

8. Haumann M, Schönweiz A, Breitzke H, Buntkowsky G, Werner $\mathrm{S}$, Szesni N. Solid-State NMR investigations of supported ionic liquid phase water-gas shift catalysts: ionic liquid film distribution vs. catalyst performance. Chemical Engineering \& Technology. 2012;35(8):1421-1426. DOI: 10.1002/ceat.201200025

9. Bian W. Room temperature ionic liquid (RTIL)-decorated mesoporous silica SBA-15 for papain immobilization: RTIL increased the amount and activity of immobilized enzyme. Materials Science and Engineering C. 2012;32:368.

10. Qiao K, Hagiwarab H, Yokoyamaa G. Acidic ionic liquid modified silica gel as novel solid catalysts for esterification and nitration reactions. Journal of Molecualr Catalysis A: Chemical. 2006;246(1-2):65-69. doi:10.1016/j.molcata.2005.07.031

11. Li H, Bhadury PS, Song B, Yang S. Immobilized functional ionic liquids: efficient, green, and reusable catalysts. $R S C$ Advances. 2012;44:12525-12551. DOI: 10.1039/C2RA21310A
12. Chrobok A. Supported hydrogenosulfate ionic liquid catalysis in Baeyer-Villiger reaction. Applied Catalysis A. 2009;366(1):2228. DOI: 10.1016/j.apcata.2009.06.040

13. Zhang X, Wang D, Zhao N, Al-Arifi AS, Aouak T, Al-Othman ZA, Wei W, et al. Grafted ionic liquid: Catalyst for solventless cycloaddition of carbon dioxide and propylene oxide. Catalysis Communications. 2009;11:43-46.

14. Huo QM, Margolese D, Ciesla U, Demuth DG, Feng P, Gier $\mathrm{T}$, et al. Organization of organic molecules with inorganic molecular species into nanocomposite biphase arrays. Chemistry of Materials. 1994; 6(8):1176 - 1191. doi: 10.1021/cm00044a016

15. Bagshaw SE, Prouzet E, Pinnavaia TJ. Templating of mesoporous molecular sieves by nonionic polyethylene oxide surfactants. Science. 1995;296(5288):1242-1244.

16. Prouzet E, Boissiére C. A review on the synthesis, structure and applications in separation processes of mesoporous MSU-X silica obtained with the two-step process. C.R. Chimie. 2007;8:579-596.

17. Peña JD, Cardona EM, Marín JM, Rios LA. Producción de sílice mesoporosa empleando monoestearato de glicerol como porógeno oleoquímico. Información Tecnológica. 2009;20(6):6774. doi:10.1612/inf.tecnol.4109cit.08

18. Skoda-Földes S. Use of supported acidic ionic liquids in organic synthesis. Molecules. 2014;19:8840-8884.

19. Amarasekara AS, Owereh OS. Synthesis of a sulfonic acid funciotionalized acidic ionic liquid modified silica catalyst and applications in the hydrolysis of cellulose. Catalysis Communications. 2010;11:1072-1075.

20. Jiang N, Jin H, Mo Y, Prasetyanto EA, Park SE. Microporous and Mesoporous Materials. 2011;141:16-19.

21. Wang F, Zhang W, Yang J, Wang L, Lin Y, Wei Y. Immobilization of room temperature ionic liquid (RTIL) on silica gel for adsorption removal of thiophenic sulfur compounds from fuel. Fuel. 2013;107:394-399. doi:10.1016/j.fuel.2012.11.033

22. Lee EL, Wachs IS. In Situ Raman Spectroscopy of SiO2Supported Transition Metal Oxide Catalysts: An Isotopic 180-160 Exchange Study. The Journal of Physical Chemistry. C. 2008;112:6487-6498. DOI: 10.1021/jp076485w 